\title{
The Impact of Ethical Leadership on Employee Performance: The Mediating Role of Employee Engagement and Organizational Citizenship Behavior (OCB)
}

\author{
Wiwik Robiatul Adawiyah1, Beta Oki Baliartati2, Aldin Rafi3 \\ \{wiwik.r@trisakti.ac.id¹, beta.oki@trisakti.ac.id², aldinrafi10@gmail.com ${ }^{3}$ \} \\ Trisakti University
}

\begin{abstract}
A leader is a role model or example for subordinates in the organization whose attitude and behavior greatly affect the employees. Ethical leadership is needed for the company sustainability. According to previous studies, ethical leadership affects employees and overall organizational performance. This study aims to examine the effect of ethical leadership on employee performance mediated by employee engagement and Organizational Citizenship Behavior (OCB). Specifically, it clarifies the relationship between Ethical Leadership and Employee Performance mediated by employee engagement and Organizational Citizenship Behavior (OCB). Quantitative research methods and the Structural Equation Model were used to test the hypothesis. The respondents comprised of 207 outsourcing employees of service companies, such as banking and construction in Jakarta. The results show that Ethical Leadership positively affects Employee Performance with Employee Engagement as mediation. Furthermore, the effect of Ethical Leadership on Employee Performance is mediated by Organizational Citizenship Behavior (OCB). This contradicts a previous study, which showed that OCB is a mediating variable for the effect of ethical leadership on employee performance. However, this study contributes to knowledge about the relationship between ethical leadership and employee performance and helps understand the role of Organizational Citizenship Behavior (OCB).
\end{abstract}

Keywords: Ethical Leadership; Employee Performance; Employee Engagement; Organizational Citizenship Behavior

\section{Introduction}

Business competition is increasing with globalization amid the global pandemic caused by the Covid-19. As a result, sustainable competitiveness requires high employee performance, such as through ethical leadership. Brown et al. (2005) defined ethical leadership as behavior consistent with prevailing values and norms through personal and interpersonal relationships between leaders and employees [1]. Furthermore, it determines employee's ethical behavior and punishes or sanctions its violators. Moreover, ethical leadership arranges a work 
environment in a fair, honest, trustworthy, and caring manner. It acts wisely and is full of good values, perseverance, and authority in making decisions. Leaders with these characteristics dominate the battlefield currently facing a common enemy with the COVID-19 virus.

Yates (2011) stated that ethical leadership affects the followers' positive attitudes and behaviors measured by employee performance, job engagement, and satisfaction [2]. According to Malik (2016), it provides a strong foundation and improves organizational performance when combined with strong values [3]. Moreover, Jajuk (2015) showed that ethical leadership affects performance and organizational commitment as a part of the engagement [4]. Similarly, Yang \& Wei (2018) found that ethical leadership could affect Organizational Citizenship Behavior (OCB), increasing performance [5]. A higher employee engagement increases job satisfaction and success in completing their work. These results could be a basis for whether their performance is good because it is a company's concern. Furthermore, a higher level of success in achieving company goals improves performance. This performance could be a benchmark to determine how the company is working. Therefore, the company should make changes to improve performance.

Many other factors also improve company performance, despite leadership. According to Alagraja \& Shuck (2015), Lewiuci \& Mustamu (2016), Muliawan et al. (2017), employee engagement improves performance [6]-[8]. Furthermore, Organizational Citizen Behavior (OCB) is a variable that could improve job performance [9]. Based on some research, OCB acts as a mediating variable. Baron \& Kenny (1986) explained that Ethical Leadership could affect OCB, which also influences performance. Moreover, the two variables, engagement, and OCB could be mediating variables for the effect of Ethical Leadership on employee job performance [10]. This supports Khokhar \& Zia-ur-Rehmen (2017), which hypothesized that ethical leadership affects Employee Performance through Engagement and OCB [11]. However, according to Sugianingrat 2019 and Khokhar \& Zia-ur-Rehmen (2017), regarding $\mathrm{OCB}$ as a mediating variable, the effect of Ethical Leadership on performance is insignificant [9], [11]. Therefore, this study uses different units of analysis to show whether the results are consistent with the theory proposed. This theory is entitled The Effect of Ethical Leadership on Employee Performance Mediated by Employee Engagement and Organizational Citizenship Behavior.

\section{Literature Review}

\subsection{Definition of Ethical Leadership}

Ethical leadership was first conceptualized by Brown et al. (2005) as behavior consistent with prevailing values and norms through personal and interpersonal relationships between leaders and employees. It implements ethical behavior, rewards anyone working ethically, and imposes sanctions [1]. Brown \& Trevino (2006) stated that ethical leaders are honest, caring, trustworthy, make fair decisions, and behave ethically in personal life and at work [12]. Furthermore, they always communicate about ethics, practice ethical behavior, and become role models. Malik et al. (2016) stated that ethical leadership communicates ethical standards and ensures they are followed by rewarding and punishing [3]. The leaders practice ethical behavior at work and in daily life. Furthermore, Yates (2011) stated that ethical leadership affects the followers' positive attitudes and behaviors measured by employee performance, job engagement, and satisfaction [2]. 


\subsection{Definition of Employee Engagement}

The concept of employee engagement was first developed by Kahn (1990) as a company or organization's personnel's identification with their work. When they are engaged, they work and express themselves physically, cognitively, and emotionally to show their performance [13]. Furthermore, Agarwal (2017) defined it as highly dedicated, motivated, ambitious, and strives to achieve additional excellence [14]. They lead as an example to others and make their ambitions consistent with organizational goals .

Schaufeli et al. (2001) stated that employee engagement is a positive psychological condition related to work [15]. These psychological conditions are characterized by vigor (spirit), dedication, and absorption. Vigor (spirit) is willing to invest a high level of energy and mentality at work without giving up easily. Dedication is the level of employee engagement to work with enthusiasm, inspiration, pride, and a feeling of being challenged. Absorption is employees' ability to fully concentrate on their work joyfully without separating themselves from their tasks, making time to pass quickly.

Amhalhal et al. (2015) defined this engagement as the relationship between an organization and its employees [16]. It is the intellectual and emotional commitment to the organization and work. Furthermore, it relates to how job performance is associated or in line with organizational results. Robinson et al. (2004) defined employee engagement as their positive attitude and the values adopted by the company. An engaged employee is aware of the organizational business context and works with colleagues to achieve company goals [17]. Therefore, companies should maintain and foster engagement, which requires two-way communication. The definitions in previous research show that employee engagement is a psychological condition with a positive impact, as well as physical and mental motivation. It is characterized by high dedication, motivation, ambition, and feelings of pleasure at work.

\subsection{Type of Employee Engagement}

Saks (2006) stated two types of employee engagement [18]:

Job Engagement

Job engagement is an employee's positive and satisfying relationship with work [19].

Organization Engagement

Farndale et al. (2014) defined this engagement as the employees' positive attitude toward the organization and their actions as ambassadors [20].

\subsection{Definition of Employee Performance}

Gibson et al. (2012) defined performance as the success in completing work and achieving company goals [21]. Moreover, Jajuk (2015) defined performance as the work achieved in performing the tasks assigned to employees based on their experience, sincerity, and time [4]. Obicci (2015) stated that employee performance results from actions towards achieving goals according to predetermined standards [22]. It could be observed directly as an action or mental product, such as an answer or decision, producing organizational or company results through goal achievement. In line with this, Agustinus (2015) defined it as a reflection of the work results. Suryadi (2012) defined performance as the work results achieved by an individual or group in the company, in line with their respective authorities and responsibilities. They aim to achieve company goals according to morals and ethics without violating the law. According to Arik (2016), employee performance comprises behaviors 
contributing to achieving organizational goals. Furthermore, based on expert definition, employee performance reflects the work achieved in completing the assigned tasks according to experience, sincerity, and time. It contributes to the achievement of organizational or company goals. The result is a benchmark of whether employees work according to company standards.

\subsection{Factor affecting Employee Performance}

Arik (2016) stated that factors affecting employee performance are grouped into two dimensions:

a) Individual Dimensions

1. Ability

Ability is the employees' capacity to complete various tasks in their work. It assesses an individual's intellectual and physical abilities.

2. Work experience

Work experience is the time spent to acquire knowledge, skills, and attitudes according to the task being performed. Companies choose more experienced employees to perform job responsibilities. As a result, the company does not incur costs for lessexperienced employees.

3. Work motivation

An employee's motivation to achieve company goals makes them more engaged in their work, increasing performance.

b) Organizational Dimensions

1. Leadership

Leadership is used to achieve predetermined goals through controlling, directing, affecting thoughts, feelings, or behavior. The leader sets goals and controls, directs, and affects thoughts, feelings, or behavior to improve employee performance.

2. Communication

Communication is a basic need of every human being to convey and respond to ideas from others. Similarly, an employee communicates with others or subordinates in the workplace.

3. Organizational Climate

Organizational climate is how members understand their internal work environment analyzed through dimensions that affect their behavior in the workplace.

\subsection{Definition of Organizational Citizenship Behavior}

Organ et al. (2006) defined OCB as individual behavior free from consideration, not directly recognized by the formal reward system, and promotes an organization's effective functioning [23]. According to Rayner et al. (2012), OCB refers to employees with more value and could improve the company's productivity [24]. Furthermore, MacKenzie et al. (2000) and Jung and Hong (2008) defined it as employees' discretionary behavior directly promoting an organization's effective functioning, regardless of its productivity goals [25], [26].

Morhead and Griffin (2012) defined OCB as the employees' behavior and not part of their main job, but supports the organization's effective functioning. According to Greenberg (2008), it is a positive individual behavior, such as helping and working outside of their 
assigned duties without expecting a reward [27]. Furthermore, Kumar et al. (2009) defined OCB as individual behavior contributing to its creation [28]. These expert opinions indicate that $\mathrm{OCB}$ is a voluntary behavior and not a forced action to prioritize the organization's interests for employee satisfaction or contribution to the company.

\subsection{Organizational Citizenship Behavior Factors}

Podsakoff et al. (2000) stated the following OCB factors [25]:

a) Employee characteristics

They are individual psychological factors, such as personality and attitudes. Patient, optimistic, honest, empathetic, and team-oriented attitudes prove organizational citizenship behavior.

b) Work characteristics

This concerns identifying task characteristics of job outcomes and their combinations to form different jobs related to employee motivation, job satisfaction, and performance.

c) Organizational characteristics

This concerns the behavior towards an organization's internal and external conditions. The focus is on people within the organization as company assets and external social responsibilities.

d) Leadership characteristics

Leadership is the creative spirit and focused thinking that directs employees to achieve maximum results with the least possible problems and significant work.

\subsection{Organizational Citizenship Behavior Dimension}

Williams and Anderson (1991) and Podsakoff et al. (2009) stated the following two important OCB dimensions related to the target and direction of employee behavior [29].

a) OCBI, Organizational Citizenship Behavior Individual (OCBI) is directed to benefit individuals in an organization, including altruism, courtesy, peacekeeping, and cheerleading.

b) OCBO, Organizational Citizenship Organizational Behavior (OCBO) benefits the organization as a whole. It comprises responsibility (conscientiousness), civic virtue, and sportsmanship [29].

Organ et al. (2006) stated the following five OCB dimensions [23]:

a) Altruism

It is the behavior of helping fellow employees with difficulties in completing their tasks. For instance, employees recovering from illness and unable to perform the job are assisted by healthy colleagues. This dimension refers to the assistance provision outside their obligation.

b) Sportsmanship

It is an attitude in which employees view each task positively regardless of disturbances or unideal conditions and work without complaining. The high scores in this dimension increase a positive climate. Employees become more polite and cooperate with others, creating a pleasing work environment.

c) Conscientiousness

It is the employees' behavior of carrying out obligations beyond the existing company requirements or exceeding expectations. 
d) Courtesy

It is good and respectful behavior of teaching others before they make problem-solving decisions related to their work. An example is providing solutions to reduce the problem development. In this dimension, employees maintain good relations with colleagues, respect, and care for others.

e) Civic Virtue

It is a behavior that indicates an employee's responsibility in organizational life and is related to active participation in relationships. Examples include following information about changes in the company, recommending improvements in organizational operations, and protecting the resources.

\section{Conceptual Framework}

The previous description shows that ethical leadership refers to a leader that communicates ethical standards. The leaders ensure that these ethical standards are followed by applying rewards and punishments. Moreover, they always practice ethical behavior at work and in daily life [3]. Therefore, the company should choose employees and leaders whose traits build a more ethical and fairer environment and motivate them to be more engaged in their work [30]. Rachna (2017) defined employee engagement as someone highly dedicated, motivated, ambitious, and strives to achieve additional excellence [14]. Moreover, they lead as an example to others and are consistent with organizational goals. It consists of job and organization engagement. A higher engagement increases organizational commitment and reduces turnover intention, improving job satisfaction (Sandi et al., 2018). According to Sugianingrat et al., ethical leadership affects employee performance mediated by their engagement [9].

This research adds OCB as a mediating variable as in several previous research. Baron \& Kenny (1986) explained that ethical leadership affects OCB, which affects job performance [10]. This is in line with Khokhar and Zia-ur-Rehmen (2017) [11]. Sugianingrat et al. (2019) and Khokhar \& Zia-ur-Rehmen (2017) showed that OCB could not mediate the effect of ethical leadership on employee performance. Therefore, this study analyzes further whether OCB mediates the effect of ethical leadership on employee performance [9], [11].

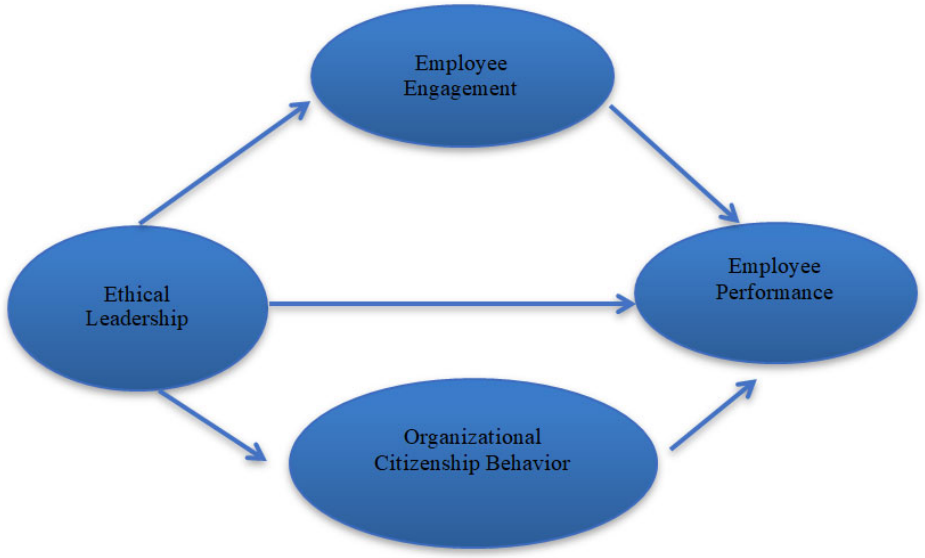

Fig.1. Conceptual Framework 


\section{Hypothesis Development}

Ethical leadership affects employee performance. Zehir, C. and Erdogan, E. (2011) explained that leaders impact employees' decisions about giving opinions or remaining silent, meaning that company leadership is very important [31]. In this case, ethical leadership strongly supports free speech behavior, making employees confident in giving opinions and accepting constructive criticism, improving their performance.

Jajuk (2015) stated that ethical leadership positively and significantly affects employee performance, while this research explains that it also affects organizational commitment [4]. This means that performance increases with better ethical leadership or stronger organizational commitment. Obicci (2015) stated that ethical leadership positively affects performance when leaders emphasize moral values and goals in decision-making procedures [22]. Also, they clarify to their employees how they contribute to achieving important company goals and improving their performance.

Awais, Timsal, and Qureshi (2016) showed a significant positive effect of ethical leadership on employee performance with a value of $\beta$ and a significance of 0.000 [3]. Employees are expected to fulfill moral standards and distinguish between them and immoral behavior. This is because ethical leaders cannot reward immoral behavior, even when it leads to success. This means that success is not determined by the final result but by how it is achieved. Therefore, ethical leadership affects performance positively. According to Malik et al. (2016), it provides a strong foundation but improves performance when combined with strong organizational values [3].

Based on this statement, the hypothesis is formulated as follows: H1: Ethical Leadership positively affects Employee Performance.

This research proposes that employee engagement mediates the effect of ethical leadership on employee performance. According to Zehir, C., and Erdoan, E. (2011), leaders affect employee decisions. Additionally, ethical leadership style strongly supports freedom of speech, improving their performance [31]. Obicci (2015) stated that leaders could emphasize moral values and goals in decision-making through ethical leadership [22]. Also, they could clarify how employees contribute to achieving important company goals, improving their performance.

Sugianingrat. IA et al. (2019) stated that ethical leadership could implement fairness, power-sharing, role clarification, people-oriented behavior, integrity, guidance, and concern for the company's sustainability. This increases vigor (spirit), dedication, absorption, and engagement [9]. Rich (2010) stated that engaged employees invest their energy into their work, increasing their performance. This is because they work with greater intensity and are more focused and responsible [32]. Furthermore, Muliawan et al. (2017) stated that the employees' desire to develop should be balanced through the company's efforts [8]. This includes freedom in completing their work or mutual respect and assistance among colleagues, which increases their performance.

Based on this statement, the hypothesis is formulated as follows:

H2: Employee Engagement mediates the effect of Ethical Leadership on Employee Performance.

Based on Podsakoff et al. (2000), Yang \& Wei (2018), as well as Khokhar \& Zia-urRehmen (2017) and Sugianingrat et al. (2017), OCB mediates the effect of Ethical Leadership on Employee Performance [5], [25]. Therefore, the third hypothesis is:

H3: Organizational Citizenship Behavior mediates the effect of Ethical Leadership on Employee Performance. 


\section{Research Methodology}

This quantitative research refers to Sugianingrat. I. A. et al., (2018) and Khokhar \& Zia-urRehmen (2017) [9], [11]. It examines the role of Employee Engagement and OCB as mediating variables in the effect of Ethical Leadership on Employee Performance. The research gap in testing OCB showed no significant mediation effect of ethical leadership on performance. However, some studies show the role of OCB as a mediating variable. Therefore, this study uses hypothesis testing to explain certain relationships or differences between groups or the independence of factors in a situation. The Structural Equation Model (SEM) method was used to test the hypothesis.

Each statement was tested for validity to ensure that the research instrument produces the right results [33]. The validity test was carried out using the factor analysis method based on the SEM factor loading. Furthermore, reliability tests were performed to ensure the measuring instruments used were consistent and reliable. The questionnaire is declared consistent when the Cronbach's alpha value is at least 0.60 [34]. This research uses cross-sectional data collected only once, while the analysis unit comprises outsourcing employees of banking service companies and contractors in Jakarta. Convenience sampling was used to select 207 respondents for this study.

\subsection{Definition of Operational Variable}

This research consists of independent, dependent, and mediating variables.

a) Independent variable

An Independent variable affects the dependent variable. Ethical leadership is an independent variable in this research. According to Brown (2005), this variable is measured using ten statement items [1], as follows:

1. The manager listens to what employees say.

2. The manager penalizes the employees for violating ethical standards.

3. The manager leads an ethical life.

4. The manager considers the interests of employees.

5. The manager makes fair and balanced decisions.

6. The manager is trustworthy.

7. The manager discusses business ethics or values with employees.

8. The manager sets an example of behaving ethically.

9. The manager determines success by results and by how success is achieved.

10. The manager decides by asking whether it is the right thing to be carried out.

b) Dependent variable

The dependent variable is affected by the independent variable. Employee performance is the dependent variable in this research. This variable is measured using six statement items as follows:

1. Understands the criteria for job performance in their organization

2. Understands their job and how to perform.

3. Completes unexpected schedules on time.

4. Maintains a good presence in this organization.

5. Performs the assigned tasks effectively and efficiently.

6. Familiar with the standard operating procedures of their job. 
c) Mediating variable

The two mediating variables in this research are Employee Engagement and Organizational Citizenship Behavior (OCB). According to Saks (2006), the two types of employee engagement are job and organization engagement, measured using nine statement items [18], as follows:

Job engagement

1. Dedicate themselves to work.

2. Sometimes they like their job and lose track of time.

3. Their mind is not going anywhere, and they do not think about other things while working.

4. Very involved in this work.

Organization engagement:

1. Being a part of this organization is very exciting.

2. One of the most enjoyable things is being involved with things happening in this organization.

3. Completely up to date on things happening in this organization

4. Being a part of this organization makes them feel alive

5. Very involved in this organization

OCB was measured by a questionnaire developed by Organ (1988) and Chiang \& Hsieh (2012) [35], [36]. It consists of four dimensions, including altruism, sportsmanship courtesy, conscientiousness, and civic virtue, translated into the following statements:

1. Help those absent

2. On-time

3. Volunteer for unneeded things

4. Orienting new employees even when not required

5. Work attendance above the norm

6. Helping those with a heavy workload

7. Give advance notice in case they cannot come to work

8. Not taking unnecessary leave from work

9. Helping supervisors with work

10. Make innovative suggestions to improve the department

11. No need for additional rest

12. Attending unnecessary events but with potential help to company's image

13. Do not waste time on unimportant conversations.

All the statement items use an interval measurement scale based on the Likert scale with the following conditions:
a. Score 1 for Strongly Disagree
b. Score 2 for Disagree
c. Score 3 for Quite Agree
d. Score 4 for Agree
e. Score 5 for Strongly Agree 


\subsection{Data Quality Test}

The data quality test results for all statements in the Ethical leadership variable found that the second indicator did not fulfill the validity test. Furthermore, for the Employee Engagement variable, indicators 1 and 2 do not fulfill the validity test. For the Organizational Citizenship Behavior variable, indicators 1, 2, and 13 do not pass the validity test because the factor loading value is below 0.4 [34]. Also, the minimum limit for the 200-249 sample is 0.4. As for the Employee Performance variable, all statement indicators pass the validity test. The indicators that fail to pass are not included in the reliability and hypothesis testing. The reliability test results for all indicators of each variable passed because Cronbach's alpha value was above 0.6 . The data quality test results are in the followings tables:

Table 1. Ethical Leadership Validity Test

\begin{tabular}{cc}
\hline Indicator & Factor Loading \\
\hline EL1 & .539 \\
EL2 & $.397^{*}$ \\
EL3 & .441 \\
E1 4 & .636 \\
EL5 & .769 \\
EL6 & .722 \\
EL7 & .542 \\
EL8 & .757 \\
EL9 & .692 \\
EL10 & .770 \\
\hline Source: Amos 21 Data Processing
\end{tabular}

Table 2. Employee Performance Validity Test

\begin{tabular}{cc}
\hline Indicator & Factor Loading \\
\hline EP1 & .482 \\
EP2 & .761 \\
EP3 & .666 \\
EP4 & .607 \\
EP5 & .674 \\
EP6 & .577 \\
\hline Source: Amos 21 Data Processing
\end{tabular}

Table 3. Employee Engagement Validity Test

\begin{tabular}{cc}
\hline Indicator & Factor Loading \\
\hline EE1 & $.352^{*}$ \\
EE2 & $.073^{*}$ \\
EE3 & .459 \\
EE4 & .715 \\
EE5 & .760 \\
EE6 & .796 \\
EE7 & .856 \\
EE8 & .657 \\
EE9 & .762 \\
\hline Source: Amos 21 Data Processing
\end{tabular}


Table 4. Organizational Behavior Validity Test

\begin{tabular}{cc}
\hline Indicator & Factor Loading \\
\hline OCB1 & .322 \\
OCB2 & .318 \\
OCB3 & .550 \\
OCB4 & .586 \\
OCB5 & .607 \\
OCB6 & .628 \\
OCB7 & .464 \\
OCB8 & .528 \\
OCB9 & .558 \\
OCB10 & .521 \\
OCB11 & .510 \\
OCB12 & .642 \\
OCB13 & .352 \\
\hline Source: Amos 21 Data Processing
\end{tabular}

Table 5. Reliability Test

\begin{tabular}{|c|c|}
\hline Variable & Cronbach's Alpha \\
\hline Ethical Leadership & .833 \\
\hline Employee Performance & .832 \\
\hline Employee Engagement & .686 \\
\hline Organizational Citizenship Behavior & .759 \\
\hline
\end{tabular}

\subsection{Model Fit Test (Goodness of Fit Test)}

Before analyzing the hypotheses, the model's overall fit should be assessed to ensure that it describes the causal effect. The following are the GoodnessGoodness of fit test results:

Table 6. The Test Results of Goodness of Fit Model

\begin{tabular}{ccccc}
\hline Measurement Type & Measurement & Cut Off & Value & Conclusion \\
\hline Absolute Fit Indices & GFI & GFI $\geq 0,90$ & 0,750 & Poor Fit \\
& RMSEA & RMSEA $\leq 0,08$ & 0,80 & Goodness of fit \\
& RMR & RMR $\leq 0,80$ & 0,071 & Goodness of fit \\
Incremental Fit Indices & NFI & $0,90 \leq$ & 0,601 & Poor fit \\
& TLI & $0,90 \leq$ & 0,689 & Poor fit \\
& CFI & $0,90 \leq$ & 0,712 & Poor fit \\
& RFI & $0,90 \leq$ & 0,569 & Poor fit \\
Persimony Fit Indices & AGFI & $\geq$ GFI & 0,712 & Poor fit \\
& PNFI & $\geq$ NFI & 0,556 & Poor fit \\
\hline
\end{tabular}

Source: Data processed using AMOS 21

Table 6 indicates that the test model is feasible because the RMSEA and RMR values meet the criteria of GoodnessGoodness of fit, meaning that it is useful for hypothesis testing. 


\section{Results and Discussion}

The hypotheses in this research include three path analysis results. First, ethical leadership positively affects employee performance. Second, ethical leadership affects employee performance mediated by employee engagement. Third, ethical leadership affects employee performance mediated by organizational citizenship behavior. Data analysis shows that employee engagement and OCB mediate the effect of ethical leadership on performance positively and significantly. The conclusion is shown in the following image:

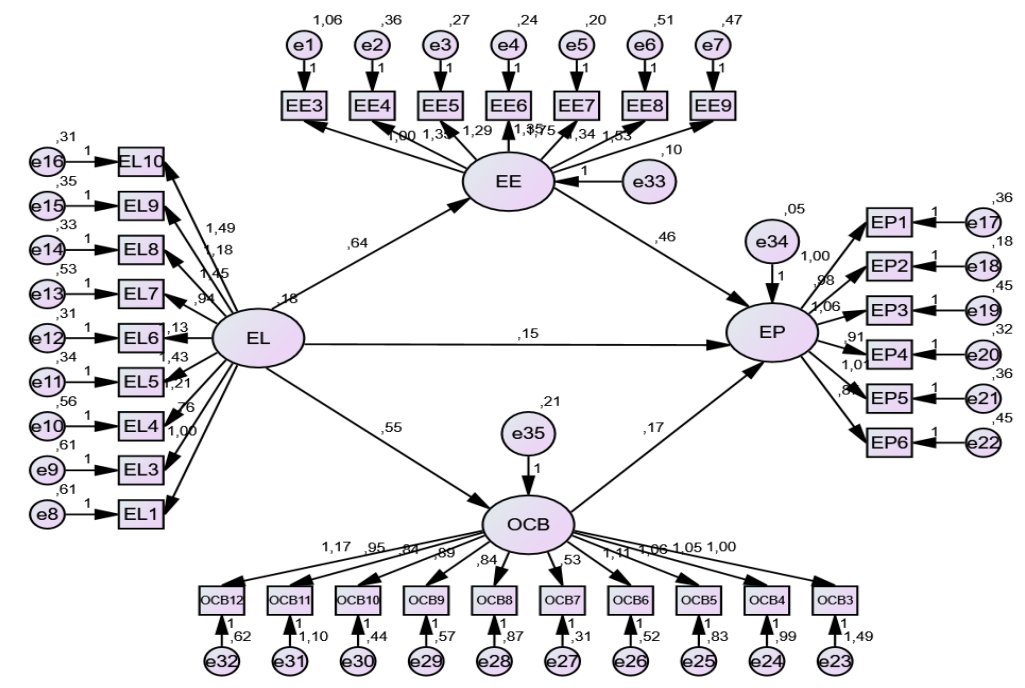

Fig. 2. Effect of Ethical leadership on Employee Performance mediated

by Employee Engagement and OCB

Figure 2 shows that high ethical leadership in the company improves employee performance. Furthermore, employee engagement and OCB mediate the effect of ethical leadership on performance. Therefore, the hypothesis testing results indicate that $\mathrm{Ha}$ is accepted. This is supported by the SEM results as shown in Table 7:

Table 7. Hypothesis Test Results

\begin{tabular}{|c|c|c|c|c|c|c|c|c|c|}
\hline & & & $\stackrel{\overrightarrow{8}}{\stackrel{8}{0}}$ & 䒿 & 近 & نُّ & 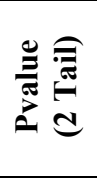 & 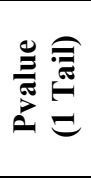 & 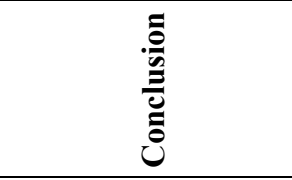 \\
\hline $\mathrm{EE}$ & $<--$ & EL & + & 0,643 & 0,159 & 4,039 & 0,000 & 0,000 & Significantly positive \\
\hline OCB & $<--$ & EL & + & 0,549 & 0,157 & 3,488 & 0,000 & 0,000 & Significantly positive \\
\hline EP & $<--$ & EL & + & 0,146 & 0,101 & 1,444 & 0,149 & 0,075 & H1 accepted* \\
\hline EP & $<--$ & $\mathrm{EE}$ & + & 0,463 & 0,136 & 3,391 & 0,000 & 0,000 & Significantly positive \\
\hline EP & $<--$ & $\mathrm{OCB}$ & + & 0,173 & 0,074 & 2,347 & 0,019 & 0,010 & Significantly positive \\
\hline
\end{tabular}


Table 7 shows that the p-value of the effect of ethical leadership on employee performance is 0.075 with a significance level of $10 \%$, meaning that the impact is positive. This supports Zehir, C. and Erdogan, E. (2011), which showed that leaders influence employee decisions to give opinions or remain silent, meaning that company leadership is very important [31]. In this case, ethical leadership strongly supports freedom of speech, making employees confidently give opinions and accept constructive criticism, eventually improving their performance. This is in line with Malik et al. (2016), which found a significant positive effect of ethical leadership on performance with a value of $\beta$ and a significance of 0.000 [3]. The implementation of ethical leadership by the companies in this research was seen from the respondents' answers with an average of 4.5710 on this variable. The variable positively and significantly impacted performance, as seen from the hypothesis testing results. Ethical leadership could be applied by exemplifying behavior to subordinates, punishing unethical employees, and listening and respecting the subordinates' opinions. This has a major impact on improving employee performance.

The SEM analysis results show that Employee Engagement mediates the effect of ethical leadership on performance. Table 7 shows that ethical leadership positively affects engagement, with a p-value of 0.000 and a $\beta$ of 0,643 . Similarly, employee engagement positively affects performance, with a p-value of 0.000 and $\beta$ of 0,463 ). Furthermore, the significance test using the Sobel test supports the SEM analysis results. The results of the Sobel test for the second hypothesis are in Table 8 :

Table 8. Significance Test Results Employee Management mediates the effect of Ethical Leadership on Employee Performance

\begin{tabular}{|c|c|c|c|c|c|}
\hline & Input: & & Test statistic: & Std. Error: & $p$-value: \\
\hline$a$ & 0.643 & Sobel test: & 2.60441633 & 0.1143093 & 0.00920309 \\
\hline$b$ & 0.463 & Aroian test: & 2.55903051 & 0.11633664 & 0.01049645 \\
\hline & 0.159 & Goodman test: & 2.65230592 & 0.11224535 & 0.00799441 \\
\hline & 0.136 & Reset all & \multicolumn{3}{|c|}{ Calculate } \\
\hline
\end{tabular}

Source: Amos 21 Data Processing

The Sobel test results in Table 8 show a p-value of 0.0092 , below the $5 \%$ significance level. Therefore, the second hypothesis that employee management mediates the effect of ethical leadership on its performance is accepted. This is in line with Sugianingrat. I. A et al. (2018) [9]. Some research on employee engagement and performance show a strong relationship between the two [8]. Moreover, ethical leadership increases employee engagement, meaning that it indirectly affects performance.

The third hypothesis test results in Table 9 show that OCB mediates the effect of ethical leadership on employee performance. The effect of ethical leadership on OCB has a p-value of 0.000 and $\beta=0.549$, implying a positive effect. Furthermore, the test results on the effect of OCB on employee performance show a $p$-value of 0.019 and $\beta=0.173$, implying a significant positive effect. This proves that OCB mediates the effect of ethical leadership on performance, supporting the Sobel test significance results in Table 9: 
Table 9. Significance Test Results Organizational Citizenship Behavior (OCB) mediates the effect of Ethical Leadership on Employee Performance

\begin{tabular}{|c|c|c|c|c|c|}
\hline \multicolumn{2}{|r|}{ Input: } & \multirow[b]{2}{*}{ Sobel test: } & Test statistic: & Std. Error: & $p$-value: \\
\hline$a$ & 0.549 & & 1.94349687 & 0.04886913 & 0.05195615 \\
\hline$b$ & 0.173 & Aroian test: & 1.89079835 & 0.05023116 & 0.05865127 \\
\hline$s_{a}$ & 0.157 & Goodman test: & 2.00086247 & 0.04746803 & 0.04540721 \\
\hline & 0.074 & Reset all & & Calculate & \\
\hline
\end{tabular}

Source: Amos 21 Data Processing

The Sobel Test significance test results show a significant level of $10 \%$, meaning that OCB mediates the effect of ethical leadership on employee performance. These results support the previous theory on the significant role of OCB on behavior in organizations. Barron \& Kenny (1986) stated that ethical leadership affects OCB, which impacts employee performance, meaning that it is a mediator [10]. However, these results contradict Khokhar. et al. (2017) and Sugianingrat I. A., et al. 1 (2018) that OCB does not mediate the effect of ethical leadership on performance. Therefore, this research reinforces previous findings [9], [11].

\section{Conclusions}

Ethical leadership positively and significantly affects employee performance. The mediating variables in this research are employee engagement and OCB and have also been shown to affect the relationship between ethical leadership and employee performance. OCB is an important factor in affecting employee behavior in organizations. This is evident from the SEM significance test results that OCB mediates the effect of ethical leadership on employee performance. However, these results contradict Khokhar et al. (2017) and Suguaningrat. I.A, et al., (2018) [9], [11].

These findings could be a reference for company leaders to apply ethical leadership that exemplifies behavior to subordinates and punishes unethical employees. Also, they listen to and respect subordinates' opinions, resulting in significant performance improvement. The company should own employee Engagement by providing opportunities to be involved in organizational activities and decision-making. These could improve employee and the overall company performance.

\section{Acknowledgments}

Praise be to God Almighty for mercy and guidance, enabling the author to complete the research entitled "The impact of Ethical Leadership on Employee Performance: The mediating role of Employee Engagement \& Organizational Citizenship Behavior (OCB)." Furthermore, this research is inseparable from the support of many parties, and gratitude is also given to:

a. Dean of the Faculty of Economics and Business, Mrs. DR. Yolanda Masnita Siagian, $\mathrm{MM}$

b. Chairman of the Council for Research and Community Service, Faculty of Economics and Business, Trisakti, Mr. DR. Jakaria 
c. And all fellow lecturers and academic staff that supported the completion of this research report.

May Allah SWT always repay all the kindness given. Furthermore, hopefully, this research could be useful for researchers and readers in general.

\section{References}

[1] M. E. Brown, L. K. Treviiño, and D. Harrison, "Ethical Leadership: A Social Learning Perspective for Construct Development and Testing," Organ. Behav. Hum. Decis. Process., vol. 97, pp. 117-134, 2005, doi: 10.1016/j.obhdp.2005.03.002.

[2] L. Yates, "Exploring the relationship of ethical leadership with job satisfaction, organizational commitment, and organizational citizenship behavior," J. Values-Based Leadersh., vol. 7, no. 1, pp. 1-14, 2011, [Online]. Available: http://scholar.valpo.edu/cgi/viewcontent.cgi?article=1093\&context=jvbl.

[3] M. S. Malik, M. Awais, A. Timsal, and U. H. Qureshi, "Impact of ethical leadership on employees' performance: Moderating role of organizational values," Int. Rev. Manag. Mark., vol. 6, no. 3, 2016.

[4] J. Herawati and P. Prayekti, "Pengaruh kepemimpinan etis dan komitmen organisasional terhadap kinerja karyawan koperasi batik di jogjakarta," SOSIOHUMANIORA J. Ilm. Ilmu Sos. Dan Hum., vol. 1, no. 1, 2015.

[5] Q. I. Yang and H. Wei, "The impact of ethical leadership on organizational citizenship behavior: The moderating role of workplace ostracism," Leadersh. Organ. Dev. J., vol. 39, no. 1, pp. 100-113, 2018.

[6] M. Alagaraja and B. Shuck, "Exploring organizational alignment-employee engagement linkages and impact on individual performance: A conceptual model," Hum. Resour. Dev. Rev., vol. 14, no. 1, pp. 17-37, 2015.

[7] R. H. Mustamu and P. G. Lewiuci, "Pengaruh Employee Engagement terhadap Kinerja Karyawan pada Perusahaan Keluarga Produsen Senapan Angin,” Agora J., vol. 4, no. 2, pp. 101-107, 2016.

[8] Y. Muliawan, B. Perizade, and A. Cahyadi, "Pengaruh Keterikatan Karyawan (Employee Engagement Terhadap Kinerja Karyawan Di PT. Badja Baru Palembang)," Jembatan-Jurnal Ilm. Manaj. Bisnis Dan Terap., 2017.

[9] I. Ayu Putu Widani Sugianingrat, S. Rini Widyawati, C. Alexandra de Jesus da Costa, M. Ximenes, S. Dos Reis Piedade, and W. Gede Sarmawa, "The employee engagement and OCB as mediating on employee performance," Int. J. Product. Perform. Manag., vol. 68, no. 2, pp. 319-339, Jan. 2019, doi: 10.1108/IJPPM-03-2018-0124.

[10] R. M. Baron and D. A. Kenny, "The Moderator-Mediator Variable Distinction in Social Psychological Research: Conceptual, Strategic, and Statistical Considerations,” J. Pers. Soc. Psychol., vol. 51, pp. 1173-1182, 1986.

[11] A. M. Khokhar and M. Zia-ur-Rehman, "Linking ethical leadership to employees' performance: Mediating role of organizational citizenship behavior and counterproductive work behavior," Pakistan J. Commer. Soc. Sci., vol. 11, no. 1, pp. 222-251, 2017.

[12] M. E. Brown and L. K. Treviño, "Ethical leadership: A review and future directions.," Leadersh. Q., vol. 17, no. 6, pp. 595-616, 2006, doi: 10.1016/j.leaqua.2006.10.004.

[13] W. A. Kahn, "Psychological conditions of personal engagement and disengagement at work,” Acad. Manag. J., vol. 33, no. 4, pp. 692-724, 1990. 
[14] R. A. Munish and R. Agarwal, "Employee engagement \& retention: A review of literature,” Int. J. BRIC Bus. Res., vol. 6, no. 1, pp. 1-19, 2017.

[15] W. B. Schaufeli, M. Salanova, V. González-Romá, and A. B. Bakker, "The measurement of engagement and burnout: A two sample confirmatory factor analytic approach,” J. Happiness Stud., vol. 3, no. 1, pp. 71-92, 2002.

[16] A. Amhalhal, J. Anchor, and S. Dastgir, "The effectiveness of the use of multiple performance measures: The influence of organizational contingencies," 2015.

[17] D. Robinson, S. Perryman, and S. Hayday, The Drivers of Employee Engagement. Brighton: Institute for Employment Studies, 2004.

[18] A. M. Saks, "Antecedents and consequences of employee engagement," J. Manag. Psychol., vol. 21, no. 7, pp. 600-619, Jan. 2006, doi: 10.1108/02683940610690169.

[19] N. Yin, "The influencing outcomes of job engagement: an interpretation from the social exchange theory,” Int. J. Product. Perform. Manag., vol. 67, no. 5, pp. 873-889, 2018, doi: 10.1108/IJPPM-03-2017-0054.

[20] E. Farndale, S. E. Beijer, M. J.P.M. Van Veldhoven, C. Kelliher, and V. Hope-Hailey, "Work and organisation engagement: aligning research and practice," J. Organ. Eff. People Perform., vol. 1, no. 2, pp. 157-176, Jan. 2014, doi: 10.1108/JOEPP-03-20140015 .

[21] J. Gibson, J. Ivancevich, J. Donnnelly Jr., and R. Konopaske, Organizations: Behavior, Structure,Processes, 14th ed. New York: McGraw-Hill, 2012.

[22] P. A. Obicci, "Effect of ethical leadership on employee performance in uganda," J. Manag. Sci., vol. 1, no. 4, pp. 245-263, 2014, doi: 10.26524/jms.2014.22.

[23] D. W. Organ, P. M. Podsakoff, and S. B. MacKenzie, Organizational citizenship behavior: Its nature, antecedents, and consequences. Sage Publications, 2006.

[24] J. Rayner, A. Lawton, and H. M. Williams, "Organizational Citizenship Behavior and the Public Service Ethos: Whither the Organization?,” J. Bus. Ethics, vol. 106, no. 2, pp. 117-130, 2012, doi: 10.1007/s10551-011-0991-x.

[25] P. M. Podsakoff, S. B. MacKenzie, J. B. Paine, and D. G. Bachrach, "Organizational citizenship behaviors: A critical review of the theoretical and empirical literature and suggestions for future research," J. Manage., vol. 26, no. 3, pp. 513-563, 2000.

[26] J. Y. Jung and S. Hong, "Organizational citizenship behaviour (OCB), TQM and performance at the maquiladora,” Int. J. Qual. Reliab. Manag., vol. 25, no. 8, pp. 793808, Jan. 2008, doi: 10.1108/02656710810898612.

[27] J. Greenberg and R. A. Baron, Behavior in Organizations. Hoboken: Pearson, 2008.

[28] J. Shi, H. Lin, L. Wang, and M. Wang, "Linking the big five personality constructs to organizational justice,” Soc. Behav. Pers., vol. 37, no. 2, pp. 209-222, 2009, doi: 10.2224/sbp.2009.37.2.209.

[29] N. P. Podsakoff, S. W. Whiting, P. M. Podsakoff, and B. D. Blume, "Individual-and organizational-level consequences of organizational citizenship behaviors: A metaanalysis.," J. Appl. Psychol., vol. 94, no. 1, p. 122, 2009.

[30] M. N. Khuong and D. T. T. Dung, "The Effect of Ethical Leadership and Organizational Justice on Employee Engagement--The Mediating Role of Employee Trust," Int. J. Trade, Econ. Financ., vol. 6, no. 4, p. 235, 2015.

[31] C. Zehir and E. Erdogan, "The association between organizational silence and ethical leadership through employee performance,” Procedia-Social Behav. Sci., vol. 24, pp. 1389-1404, 2011.

[32] B. L. Rich, J. A. Lepine, and E. R. Crawford, "Job engagement: Antecedents and effects on job performance,” Acad. Manag. J., vol. 53, no. 3, pp. 617-635, 2010. 
[33] U. Sekaran and R. Bougie, Research Methods For Business, 6th ed. United Kingdom: John Wiley \& Sons Ltd, 2013.

[34] J. F. Hair, W. C. Black, B. J. Babin, R. E. Anderson, and R. L. Tatham, Multivariate Data Analysis. Essex: Pearson Education Limited, 2014.

[35] D. W. Organ, Organizational Citizenship Behavior: The Good Soldier Syndrome. Lexington, MA: Lexington Books, 1988.

[36] C.-F. Chiang and T.-S. Hsieh, "The impacts of perceived organizational support and psychological empowerment on job performance: The mediating effects of organizational citizenship behavior,” Int. J. Hosp. Manag., vol. 31, no. 1, pp. 180-190, Mar. 2012, doi: 10.1016/j.ijhm.2011.04.011. 